\title{
Legal Process Outsourcing as Challenge for Lawyers and Archival Institutions in EU
}

\author{
DUŠAN JOVANOVIČ, ASSIS. PROF. DR.
}

Institution/Affiliation: Faculty of Economics and Business, University of Maribor, Razlagova ulica 14

SI - 2000 Maribor

e-mail address: dusan.jovanovic@um.si

\author{
PATRICIJA JANKOVIČ, AsSIS. PROF. DR. \\ Institution/Affiliation: ISMA, Institute for innovative system methods and applications, Zgornja Kungota 10j \\ SI - 2201 Zgornja Kungota \\ e-mail address: patricija.jankovic@guest.arnes.si \\ BORUT BRATINA, AsSOC. Prof. DR. \\ Institution/Affiliation: Faculty of Economics and Business, University of Maribor, Razlagova ulica 14 \\ SI - 2000 Maribor \\ e-mail address: borut.bratina@um.si
}

Legal Process Outsourcing as Challenge for Lawyers and Archival Institutions in EU

\section{ABSTRACT}

The problem of archival institutions is in lack of employees with knowledge and experiences in law. The budget financing is insufficient for employment of lawyers in archives. Therefore for important services law firms are being hired but so called smaller issues are being serviced by other employees. Stressing out different possibilities of organizing virtual law firms for low budget legal services as legal start-up's, authors argue that outsourcing is an optimal solution both for institutions and for the lawyers.

Key words: LPO (legal process outsourcing), LSO (legal service outsourcing), virtual law firms, legal start-up, legal profession

L'affidamento esterno delle procedure legali come sfida per i legali e le istituzioni archivistiche nell'Unione Europea

\section{SINTESI}

Il problema delle istituzioni archivistiche è la mancanza di funzionari con conoscenze ed esperienze di legge. Le risorse finanziarie sono insufficienti per averne. Così, in caso di procedure importanti, vengono utilizzati studi legali, mentre per questioni di minor importanza vengono utilizzati altri impiegati. Nel sottolineare diverse possibilità di organizzare studi legali virtuali per servizi legali a basso costo, gli autori concludono che l'affidamento esterno è la soluzione ottimale sia per le istituzioni che per i legali.

Parole chiave: processi legali in affidamento esterno, servizi legali in affidamento esterno, studi legali virtuali, start-up legale, professione legale

Najemanje zunanjih pravnih storitev, izziv za pravnike in arhive v EU

\section{IZVLE ČEK}

Problem arhivov je v manku kadra z izkušnjami in znanjem na pravnem področju. Proračunsko financiranje namreč ne zadošča za zaposlitve pravnikov, zato je za večje storitve potrebno najeti odvetniške pisarne, manjše in zgolj na videz nepomembne zadeve pa urejajo kar uslužbenci sami. S pomočjo prikaza različnih možnosti organiziranja nizkocenovne virtualne pravne pisarne, avtorji prikazujejo najemanje zunanjih pravnih strokovnjakov, kot optimalno rešitev tako za institucije kot tudi za pravnike.

Ključne besede: pravne storitve, zunanje najemanje storitev, virtualne pravne pisarne, start-up podjetja 


\section{Introduction}

Archives belong to the category of obligatory public services that must be provided by the state. Especially in order to preserve its cultural heritage, they are financed solely from the state or local budget. Financing archival services also includes the payment for employment. But employment policies seldom (almost never) encourage employment of lawyers or legal consultants.

Archives often face legal problems in carrying out their day to day activities or planning new projects. Due to the current situation without having lawyers on the active list is almost impossible. The only solution for archival institutions is legal service outsourcing.

The meaning of law is changing drastically due to a process where law is becoming more a good and less a service that is provided by legal professionals and law firms. The purpose of this article is to define and critically evaluate the challenges that such transformation is causing and to offer possible solutions and explanations for this global occurrence. As a good, law is rapidly entering the field of economics; in this newly shaped world, most successful will be those lawyers who will find a way to adapt.

In the era of tight economic conditions, the view on the legal profession and legal services has changed radically. The prevailing practice of accessing clients individually and offering them "universal" legal expertise has been superseded by providing knowledge belonging to narrow, specialised legal fields. Yet, it is not only specialisation that has affected the way legal services are offered, the process of evolution of legal services has also been stimulated by involvement of new technology. The ultimate goal of the emerging process was decreasing the costs of legal services, however, this was initially in total contradiction with the efforts to acquire high-quality expert legal knowledge and to ensure a 24/7 availability of lawyers to their clients. Combination of all these circumstances and goals, along with the technical advancement and easy access to internet, has led to the occurrence of legal service outsourcing (in the following referred to as "LSO"). Now, the process is slowly moving from the common law states to the states of the continental law system (the so-called transatlantic bridge).

Offering legal services to "larger" demanders in a technologically sophisticated manner has risen significantly, which has sparked the idea of offering "everyday" legal services to the legally illiterate in return of small fees, most effectively through the so-called virtual law firms. With the occurrence of LSO and legal process outsourcing (in the following referred to as "LPO"), legal service became a good and is thus subject to all the rules of business. It is safe to say that it is well past time to face the fact that law is a business - and we better start acting like businesses, or soon, we will all be out of business. The exceptional growth of this new industry's market is yet another proof of its ascent. Namely, the market of outsourced legal services jumped from 554 million USD in the year 2011 to 1,109 million USD in the year 2014, which presents a 26-percent increase ("Legal Process Outsourcing: Crisis Creates New Opportunities for LPOs," 2009).

Key questions regarding the development of LPO are the following: What are the business risks related to preparation and review of contracts worth millions of EUR? Will the quality of services be affected? What is the damage that could be caused by bad (unclear) contract clauses, bad managerial contracts, concluded employment relationships, cartels, violation of rules on competition, etc.? How much money can LPO really save? What about the risk of sharing sensitive legal information? Questions like these appear to the firms that do not have their own in-house legal departments on a daily basis. It is therefore even more important that the legal services offered on the market be of high quality, preventing any damage that could possibly be caused to the companies and individuals.

\section{Characteristics of LSO/LPO}

Basic characteristics of LSO are: savings in the view of lower costs of legal services; possibility of acquiring expert knowledge from different fields of law; better and more effective exploitation of existing legal knowledge capacities (i.e. in-house lawyers); easier hiring and better availability of personnel and resources in case of larger unexpected projects; permanent availability of services considering different time-zones and temporal difference; higher flexibility, etc. (Kane, 2009). 
The times of large law firms employing a large number of legal professionals are passing. This observation is easily demonstrated with the fact that large law firms (employing more than 250 lawyers) are hiring as much as $67,5 \%$ of (external) contractual lawyers, while this number in smaller law firms amounts only to 38,4\% (Naegle, 2014). Individuals in charge of law firms are evolving from being strictly lawyers to acting more as managers marketing their products and conducting law business ${ }^{1}$. Consequently, an increased number of lawyers from large US firms is considering establishing or have already established smaller law firms, where they are hiring cheaper legal services from abroad (mainly from India) by using modern technology (e-business) (Smith, 2011). Online providers of legal services are on the rise, since their number grew from 15 in the year 2005 to more than 200 in the year 2011 (Smith, 2011, p. 9).

Constant pressure to lower the prices has triggered intense competition amongst providers of legal services, leading to eventual lowering of prices and to a corresponding demand for higher effectiveness, with zero tolerance for any possible decrease in quality. Consequently, a conclusion can be made that from the users' viewpoint there is a permanent race to the top, while the providers of services compete amongst themselves in a race to the bottom. At the same time, LPO is recognised as a positive trend in the global economy (Smith, 2011, p. 6; "ABA Formal Opinion 08-451," 2008). It should not be overlooked that LPO enables smaller law firms and individual lawyers to run also for larger deals, with no fear of being "undernourished" in terms of knowledge or staff. Thus, LPO will clearly blossom also in the future, in relation to not only large law firms connecting with other large firms, but primarily amongst smaller law firms and individual lawyers who will be able to accomplish their goal of offering a high-quality and affordable legal service by connecting with smaller providers of legal outsourcing ${ }^{2}$.

Law firms from USA and UK consider India as their first-choice country for obtaining LPO (lately, India is followed by the Philippines and South Africa), taking into account all the characteristics of LPO. Generally, it is not the quality of legal services of Indian lawyers that is decisive (they are not recognised as better or superior), but the fact that an equally good service costs significantly less than a service rendered by an US or UK law firm (Law Without Borders, 2011: pp. 8, 10). It should be pointed out that India earned such position also due to historic facts and the official use of English language. The country is a real superpower on the legal market, having more than a million lawyers and more than 128 providers of legal outsourcing, who, in the year 2010, exported more than 640 million USD worth of legal services (Wood, 2014).

LPO has important effects also from the viewpoint of global (macro) economics, since the rise of LPO is increasing the welfare and corresponding consumerism.

When considering LPO, the well-known saying "small is beautiful" is very eloquent. Namely, the focus of legal business has switched from large law firms to boutique law firms, i.e. providers of a smaller spectrum of legal services. Such firms are proving to be more responsive, the threat of possible conflict of interests is lower, they are more specialised in specific legal areas, and are, finally yet very importantly, cheaper (Smith, 2011, p. 9).

LPO has also caused a change in orientation of legal service providers and lawyers using LSO in their everyday work - law firms and lawyers are increasingly concentrating on management and brokerage of legal services. They are thus expected to execute only the final transactions and deals, to negotiate, appear in court, supervise external consultants and give legal advice, while all the other work is done by external consultants and collaborators. As a consequence, a new branch is emerging, redirecting the lawyer from being a provider of basic legal services to being an organiser of providers of those services (Passarella, 2010).

Due to the increasing presence of the LPO process, certain warnings and concerns are coming to light, particularly regarding ("The resurgence of corporate legal process outsourcing," 2011):

Security and confidentiality. Legal work is confidential by its very nature. Many general counsels worry about transferring data to outside parties, especially if the data is being sent across oceans.

1. Important information from the year 2010 indicates that $43 \%$ of corporations and $73 \%$ of law firms use legal outsourcing (Cooper, 2011).

2. A similar viewpoint share also Brooks, 2011; Rubin, 2012; Sachdev, 2011. 
Quality. Corporate legal departments are accustomed to face-to-face interaction with the people performing legal tasks. Legal executives may fear that work performed remotely will not meet the department's quality standards. Additionally, legal executives may be unwilling to support the cost of deploying internal resources to provide quality control over LPOs-provided services.

Ethical implications. Risks related to the unauthorized practice of law made many general counsels uneasy about using LPO providers.

Client/outside counsel relationship. Whether due to the perceived threat of an LPO provider's impact on the bottom line or a lack of trust in the quality of outsourced work, legal departments had a difficult time obtaining outside counsel's buy-in for the use of LPO.

Users of LPO are overcoming these flaws principally by increasing the transparency in hiring external experts and by acquiring their clients' consent or at least approval for the work on their case to be partially executed by outside counsels. Additionally, all providers of outsourcing have to be regularly monitored and supervised and be subject to valid certification, performed by independent institutions. Moreover, LPO users themselves are responsible for verification and supervision of the providers' competences and abilities in order to ensure the best education processes, knowledge transfer and selection. On the other side, it is of the essence for the providers of outsourcing to avoid any possible conflicts of interests or inappropriate backgrounds and to assure psychological stability, adequate infrastructure and protection of data transfer and storing.

\section{LPO models}

LPO, as a result of technological influences, can be observed in different (technical) forms (Chambers et al., 2013, pp. 1, 4-6):

1. as external (foreign) LPO (mainly across-ocean outsourcing, generally from related legal systems, leading to big savings in terms of time and money due to obtaining cheaper services of the same quality);

2. as near LPO (nearsourcing) (meaning chiefly special knowledge gained through the division of work principle, where in-house lawyers retain enough time to work on special matters while the specialists in particular fields of law are hired);

3. as LPO executed by non-lawyers, which can be established as external LPO or nearsourcing (in these cases, LPO providers are performing especially the tasks of technical assistance and general legal work that can also be performed by non-lawyers).

Each of the listed technical forms can be implemented in several different manners, while certain aspects are explicitly underlined, measuring from strategic legal advice (reserved generally for law firms) through technical legal advice and general legal work to repeatable legal work. The latter is mostly attributed to external operators (outsourcing). In this way, law firms and outsourcing are approaching each other, each from its own side. As we move on the measuring rod from law firms' services to LSO providers, we can clearly identify a transformation from art into craft.

Additionally, specific characteristics of different providers of legal services need to be noted. As regards law firms, in the forefront is especially high-level complexity of their work, which is often judgment-based with priority focus on legal substance. On the contrary, legal outsourcing services are based mainly on high volume with priority focus on procedural issues.

On the grounds of such evaluation, it is achievable to indicate typical forms of outsourced legal tasks that include document review, contract and template drafting, contract review and analysis, predeal and post-deal due diligence, case law research, legal research, drafting of legal papers, legislative tracking and analysis, documents redaction, M\&A preparation, witness interviews, medical summaries, etc. ${ }^{3}$.

\footnotetext{
3. Services of legal outsourcing consist of: $26 \%$ documentation review, $22 \%$ work with contracts, $16 \%$ support in court proceedings, $15 \%$ legal research, $8 \%$ financial reviews, the residual part belongs to other services ("Legal services outsourcing: What it is \& how it could help your legal practice," 2012).
} 


\section{LPO in EU}

EU countries have long been resisting the LPO process originally introduced in the Englishspeaking common law jurisdictions, including USA, UK and Australia. Yet, regardless to the opposition, globalisation and multi-national corporations have inevitably brought this process also to EU.

Expansion of LPO has hit a number of obstacles, including different historical reasons, which is why the number of European providers of legal services remains scarce (Chamberlin, 2013, p. 4). Amongst the inhibitors of LPO in the European Union, language barriers are especially pointed out, since the significant multilingualism effectively shields EU from the invasion of foreign service providers. A further problem is also the continental law system as such, which is not unified nor harmonised in the field of procedural issues and enforcement, where lex nationalis has retained a complete dominance. Ultimately, LPO in the EU is hindered also by the conservative mentality of continental lawyers, following predominantly the "wait-and-see" approach (Chamberlin, 2013, p. 4).

Notwithstanding the negative presumptions, an increased activity in using LPO can be observed in the EU, especially as regards international business of banks and technology companies. European LPO is oriented mainly towards offering help regarding the elements of common law system and contains notably less litigation support, while the development is primarily concentrated on LPO that ensures EU privacy standards and meets quality expectations, specific to the European area. A vast majority of LPO process is related to the civil relationships, especially in the department of corporate law.

A conclusion can be made that the progression of LPO in the EU is not thoroughly following the path the common law states have taken. Yet, due to the unstoppable globalisation and international corporations that have essentially forced EU into adoption of LPO, a slightly modified LPO model has been shaped, used especially in the civil law sphere regarding contracts, representation, corporate compliance, due diligence, etc.

Unlike the autonomous U.S. regime which leans on the American Bar Association Rules, the LPO system in Europe is subject to statutory norms on data protection and quality of services. The (rare) providers of LPO are thus obliged to obtain certain certificates in order to be allowed to pursue their activities ${ }^{4}$, whereas the area of data protection is governed also by the Directive EU 95/46/EC 5 . Autonomous arrangements can also be governed by master service agreements (MSAs), taking into consideration European ius cogens.

In EU, an internal LPO process can also be observed, introducing cooperation between different member states (where LPO providers primarily originate from the UK). The LPO process is thus steadily expanding and paving the way for the lower costs of legal services. EU and its member states will have the privilege of being able to follow the example of the evolution of LPO in the USA and use the American model to properly regulate the area of LPO in terms of quality control and data protection.

\section{Legal startup's}

LPO is only one of many ways of disrupting the legal industry. There is no doubt that legal professionals have fallen asleep and have not done much to take a step with technology. There has not been done much in last decades to make legal services more attractive and young professionals decided to change that.

Legal startups are on the rise. They are introducing us with legal technology, which is how they want to disrupt the legal space at every level and from every angle and it makes much sense if we consider the market size with its 400 billion USD in the U.S. (Rubin, 2014). With the market being flooded with tech startups there are more and more clients demanding more efficient, transparent and affordable legal services, and lawyers are looking for their place under the sun (Rubin, 2014). Not only LPO but every other angle of law is being part of the transformation. We are witnessing many new

4. For example ISO 27001 (business continuity) and ISO 9001 (quality management) (Chamberlin, 2013, p. 6).

5. DIRECTIVE 95/46/EC OF THE EUROPEAN PARLIAMENT AND OF THE COUNCIL of 24 October 1995 on the protection of individuals with regard to the processing of personal data and on the free movement of such data. 
players like Axiom Law, Modria, LawBite, LegalZoom, Priori Legal, Lawdingo, etc. however they only appear in the common law system.

The continental system is traditionally more conservative, old fashioned but that is changing too. Startups, future mega players in every industry, are there too and law firms are not set up to cater for the needs of start-up business (Ingham, 2014). Virtual services and digital efficiency have brought efficiency to almost every industry and the legal sector is no exemption. High-Tech tools, cost efficiency and other skills are a must in the future of legal industry and young lawyers with these skills are on the rise. Axiom Law has signed a multimillion contract with a big bank for the momovement of highly complicated transactions onto electronic platform run by Axiom's team of lawyers and paralegals (Fisher, 2015). So even the banking sector is obviusly leaning towards the new way of law and cost optimisation which is why a new era of law is knocking on the door so better be prepared. And for the end let us point out that young lawyers are perpared to work for less which is going hand in hand with the main issue of every company after the big crisis - which is cost optimisation. And it is easier for them, the newcomers, to learn good legal skills than for expirienced old fashioned lawyers to adapt to the new business eco-system. However the best solution would be cooperation between both generations without strict hierarchy, which is mostly stopping young lawyers and the legal industry to evolve.

\section{Conclusion}

Technology and international participation in the legal process has not only allowed workers to work from lower-cost locales, but has allowed skilled domestic attorneys to provide services easily to the world. Outsourcing is a positive development, because it not only increases client access to legal services by allowing traditional clients to meet their needs on a smaller budget, but it also helps reach a new category of clients who could not afford legal services previously (Chambers et al., 2013, pp.18, 11-12).

Direct influence of LPO can be seen in the form of lower costs for clients, specialization of legal work, standardization of the questionnaire for legal outsourcing, easy legal access for all consumers and, last but not least, also less litigations, due to a better legal environment and knowledge.

It is safe to state that technology has opened the door for outsourcing in the legal profession and that outsourcing has changed the territorial and professional limits of the legal profession. Yet, the amount of questions and challenges regarding the mechanism indicates a live process that will keep evolving in order to assure that all the requirements concerning security, confidentiality, quality, ethics and client relationships are met. The service providers who will be able to provide the best service at the lowest rates will ultimately succeed. In the end, cost-efficient lawyers will be able to serve clients better in the new reality of small legal budgets.

\section{References}

Ambrogi, R. J. (2005). Virtual Justice: Resolving Disputes Online. 62 BENCH \& B. MINN. 13.

Bratina, B., Jovanovič, D. (Ed.), Podgorelec, P. \& Primec, A. (2011). Pravo družb in gospodarsko pogodbeno pravo. Maribor: De Vesta.

Brooks, E. (2011). Legal services outsourcing: don't miss the boat. The Journal of the Law Society of Scotland. Retrieved from http://www.journalonline.co.uk/Magazine/56-4/1009598.aspx.

Chamberlin, D. (2013). Sourcing Insight: LPO in Continental Europe. Retrieved from http://www.trestlegroup. com/wp-content/uploads/2013/07/TG-Sourcing-Insight_LPO-in-Europe.pdf.

Chambers, A., Lekahal, C., Nelson, K., Pyun, J. \& Wolny, G. (2013). Transformative Change: Outsourcing the Practice of Law. Retrieved from http://www.colorado.edu/law/sites/default/files/TransformativeChangeOutsourcing-2013.pdf.

Cooper, L. (2011). Legal Outsourcing - From Scepticism to Mainstream Acceptance. Retrieved from http://www.sourcingfocus.com/site/featurescomments/legal_outsourcing_from_scepticism_to_mainstream_ acceptance. 
Dušan JOVANOVIČ - Patricija JANKOVIČ - Borut BRATINA: Legal Process Outsourcing as Challenge for Lawyers and Archival Institutions in EU, 163-170

CPA Global. (2012). Legal Services Outsourcing: What it is \& how it could help your legal practice. Retrieved from

http://www.statecapitalgroup.org/meetings/chicago/CPA\%20SCG\%20-\%20Oct\%2015\%202012\%20-\%20 Chicago.pdf.

Deloitte. (2011). The resurgence of corporate legal process outsourcing - Leveraging a new and improved legal support business model. Retrieved from http://www.deloitte.com/assets/Dcom-UnitedStates/Local\%20Assets/Documents/IMOs/Shared\%20Services/US_SDT_Resurgence\%20of\%20Corporate\%20Legal\%20Process\%20 Outsourcing_WEB_113011.pdf.

Fisher, D. (2015). Legal-Services Firm's USD73 Million Deal Strips The Mystery From Derivatives Trading. Retreived from http://www.forbes.com/sites/danielfisher/2015/02/12/legal-services-firms-73-million-dealstrips-the-mystery-from-derivatives-trading/.

Garicano, L. \& Hubbard T. N. (2007). Specialization, Firms \& Markets: The Division of Labor Within \& Between Law Firms. Evanston, IL: Kellogg School of Management. Retrieved from

http://www.kellogg.northwestern.edu/faculty/hubbard/htm/research/papers/boundaries\%20061507.pdf.

Henderson, B. (2012). Predictive Coding is a Disruptive Innovation that will Change How Law is Practiced. Retrieved from

http://www.krollontrack.com/publications/PredictiveCoding.pdf

Hodges, J. (2010). Microsoft signs up to new outsourcing deal with Integreon. Legal Week. Retrieved from http://www.legalweek.com/legal-week/news/1600014/microsoft-signs-outsourcing-deal-integreon.

Ingham, E. (2014). How Do You Disrupt The Legal Industry? Offer Value The Big Firms Can't Match. Retreived from http://www.forbes.com/sites/edmundingham/2014/09/02/how-do-you-disrupt-the-legal-industry-offer-value-the-big-firms-cant-match/.

Kamping-Carder, L. (2010). Firms Look To, In-Sourcing'To Slash Costs. LAW 360. Retrieved from http://www. law360.com/legalindustry/articles/164915.

Kane, S. (2010). 10 Trends Reshaping the Legal Industry. Retrieved from http://legalcareers.about.com/od/careertrends/tp/10-trends-reshaping-the-legal-industry.htm.

Kane, S. (2009). Top Advantages of Outsourcing. Retrieved from http://legalcareers.about.com/od/careertrends/ tp/Outsourcingadvantages.htm.

LeHocky, M. (2009). A Generation of Left-Handed Spitball Throwers: A GC's Take on the Changing Legal Scene. Argyle Journal. Retrieved from http://www.argylejournal.com/general-counsel/session-transcript-mark-lehocky-senior-vice-president-general-counsel-and-corporate-secretary-ross-stores-inc.

Mendelson, J. (2009). Law Firm 2.0 - Re-architecting the Law Firm - Outsourcing. Mendelson's Musings. Retrieved from

http://www.jasonmendelson.com/wp/archives/2009/03/law-firm-20-re-architecting-the-law-firmoutsourcing.php.

Naegle, H. (2014). Legal Outsourcing: The New Law Firm Model. Retrieved from http://overflowlegalnetwork. com/legal-outsourcing-new-law-firm-model.

Nelson, M. (2013). New changes to Model Rules a wake-up call for technologically challenged lawyers. Inside Counsel. Retrieved from http://www.insidecounsel.com/2013/03/28/new-changes-to-model-rules-a-wake-upcall-for-tech.

Passarella, G. (2010). Are Law Firms Morphing Into Managers of Legal Providers? The Legal Intelligencer. Retrieved from http://www.thelegalintelligencer.com/id=1202474270432/Are-Law-Firms-Morphing-Into-Managers-of-Legal-Providers?slreturn $=20140918153150$.

Purani, S. (2011). 'LPO' should stand for Legal 'Partner' Outsourcing. LPO Savvy. Retrieved from http://lposavvy.info/index.php?option=com_content\&view=article\&id=332:-lpo-should-really-stand-for-legal-partner-outs ourcing\&catid=1:public\&Itemid $=32$.

Rio Tinto Signs Legal Services Outsourcing Agreement With CPA Global. (2009). PR Newswire. Retrieved from http://www.prnewswire.com/news-releases/rio-tinto-signs-legal-services-outsourcing-agreement-with-cpa-global-62158722.html.

Rose, B. (2010). Law, the Investment: Entrepreneurs attract major cash to draw legal services away from law firms. ABA Journal. Retrieved from http://www.abajournal.com/magazine/article/law_the_investment. 
Dušan JOVANOVIČ - Patricija JANKOVIČ - Borut BRATINA: Legal Process Outsourcing as Challenge for Lawyers and Archival Institutions in EU, 163-170

Rubin, B. (2014). Legal Tech Startups Have A Short History And A Bright Future. Retreived from http://techcrunch.com/2014/12/06/legal-tech-startups-have-a-short-history-and-a-bright-future/.

Rubin, C. (2012). Big Money for Cheap Legal Services. Inc. Retrieved from http://www.inc.com/courtney-rubin/ rocket-lawyer-raises-\$11-million.html.

Sachdev, A. (2011). Growth of legal outsourcing may herald era of cheaper lawyering. Los Angeles Times. Retrieved from http://articles.latimes.com/2011/jan/01/business/la-fi-legal-outsourcing-20110101.

Smith, R. (2011). 12 Ways Offshore Legal Outsourcing Could Shake Up the Law World in the New Decade. Law Without Borders. Retrieved from http://lawwithoutborders.typepad.com/legaloutsourcing/2011/01/12-waysoffshore-legal-outsourcing-could-shake-up-the-law-world-in-the-new-decade-.html.

Standing Committee on Ethics and Professional Responsibility of the American Bar Association. (2008). Formal Opinion 08-451: Lawyer's Obligations When Outsourcing Legal and Nonlegal Support Services. Retrieved from http://www.aapipara.org/File/Main\%20Page/ABA\%20Outsourcing\%20Opinion.pdf.

Susskind, R. (2013). Tomorrow's Lawyers: An Introduction to Your Future. Oxford: Oxford University Press.

ValueNotes. (2009). Legal Process Outsourcing: Crisis Creates New Opportunities for LPOs.

Wood, L. (2012). Legal Process Outsourcing Market in India 2010-2014. TechNavio. Retrieved from

http://www.researchandmarkets.com/research/894dd9/legal_process_outs.

\section{SUMMARY}

The problem of archival institutions is in lack of employees with knowledge and experiences in law. The budget financing is insufficient for employment of lawyers in archives. Therefore for important services law firms are being hired but so called smaller issues are being serviced by other employees. In the nearly past, the legal industry has experienced a global paradigm shift in the delivery model for legal services. This new model, known as legal process outsourcing, transfers the work of attorneys, paralegals and other legal professionals to external vendors located domestically and overseas. Legal outsourcing (both onshore and offshore) is transforming law practice as law firms and corporate legal departments seek to minimize costs, increase flexibility and expand their in-house capabilities. In this new decade, we have to prepare, with the legal services outsourcing, that we will become more sophisticated, with higher value of legal work, at higher level of quality and speed, and dramatically lower cost. In the Article authors deal with the process of the transformation of legal service into a legal good and point on some dilemmas during that process. This paper argues that outsourcing ultimately will have a positive effect on the legal profession and development of the quality of legal services. In the second part of this paper authors also stress out some information about different possibilities, how to organize virtual law firms for low budget legal services as legal start-up's.

Typology: 1.01 Original Scientific Article

Submitting date: 25.03 .2015

Acceptance date: 09.04.2015 